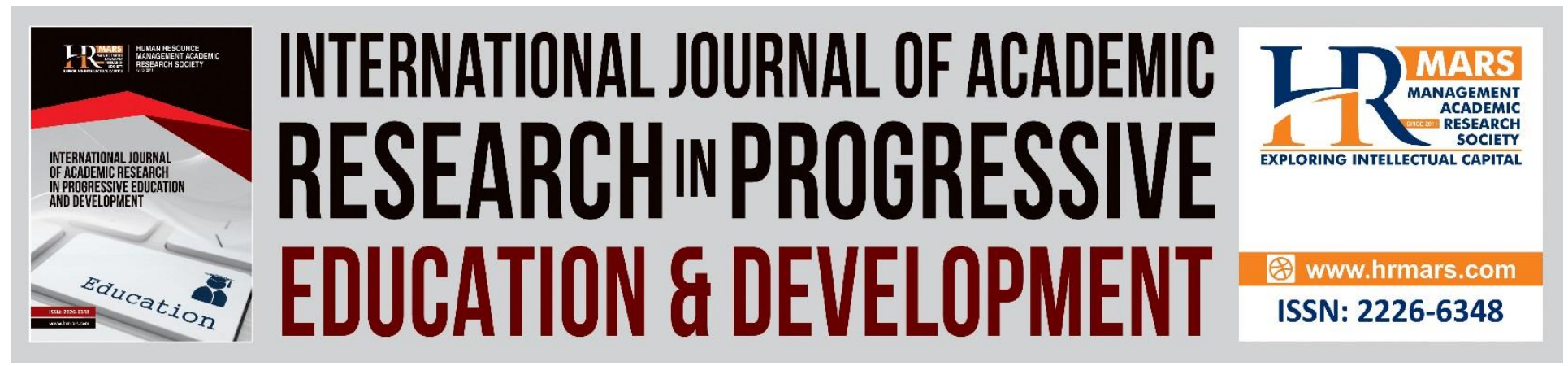

\title{
Intensity in Spirituality of High-Ability Students
}

\section{Rosadah Abd Majid \& Aliza Alias}

To Link this Article: http://dx.doi.org/10.6007/IJARPED/v8-i4/6778

DOI:10.6007/IJARPED/v8-i4/6778

Received: 10 November 2019, Revised: 29 November 2019, Accepted: 16 December 2019

Published Online: 30 December 2019

In-Text Citation: (Majid \& Alias, 2019)

To Cite this Article: Majid, R. A., \& Alias, A. (2019). Intensity in Spirituality of High-Ability Students. International Journal of Academic Research in Progressive Education and Development, 8(4), 877-885.

Copyright: (C) 2019 The Author(s)

Published by Human Resource Management Academic Research Society (www.hrmars.com)

This article is published under the Creative Commons Attribution (CC BY 4.0) license. Anyone may reproduce, distribute, translate and create derivative works of this article (for both commercial and non-commercial purposes), subject to full attribution to the original publication and authors. The full terms of this license may be seen at: http://creativecommons.org/licences/by/4.0/legalcode

\section{Vol. 8(4) 2019, Pg. 877 - 885}

Full Terms \& Conditions of access and use can be found at http://hrmars.com/index.php/pages/detail/publication-ethics 


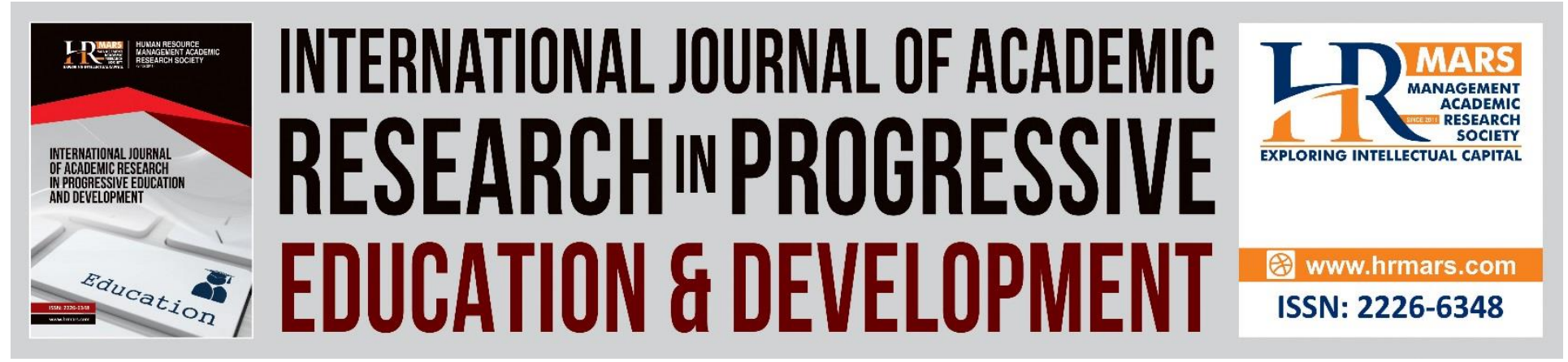

\title{
Intensity in Spirituality of High-Ability Students
}

\author{
Rosadah Abd Majid \& Aliza Alias \\ Universiti Kebangsaan Malaysia, Malaysia \\ Email: rosadah@ukm.edu.my
}

\begin{abstract}
The spirituality of an individual is primarily determined by the awareness, faith and morality pertaining to one's beliefs. The capacity to use one's multisensory approach and experiences to access inner knowledge in understanding life and belief in religion marks the nurturing of curiosity, and development of awareness of the spiritual domain for achieving wellbeing in life. Being blessed with high intensity in learning and cognition, high-ability students' curiosity has the potential to lead them into deep and meaningful understanding of faith and belief, far ahead of their peers. Therefore, religious education should address the needs of these students in understanding the morality and spiritual aspects in religious education.
\end{abstract}

\section{Introduction}

Spirituality is regarded as the essence on an individual (Phenwan, Peerawong, Tulathamkij, 2019); an aspect that requires a deep understanding of faith and belief for the person's wellbeing. Being aware of the morality and faithfulness to one's belief would develop one's personality to be closely influenced and guided by spirituality. Yearning for knowledge and wanting to embrace faith to its core has the propensity to lead one to continuous questions on the matter. Palmer (1999) defined spirituality as a quest for connectedness with self, with others, with history and nature, and with the mystery of being alive. In searching for divine answers on spirituality, one might get derailed from the meaningful quest of spirituality without constant guidance from a person who is not only knowledgeable in the belief itself but also wisely uses different approaches in tapping the interest and needs of the believer's quest.

\section{High-ability Student}

There are diverse learners enrolling in our school system in line with the efforts towards establishing inclusive education (Zalizan \& Manisah, 2014; Dollah, Zabit, \& Omar, 2018; Onyali, Okerekeoti, 2018) these include students with special needs as well as students with high ability. Students who have high ability in cognitive aspects showed certain characteristics that distinguish them from their peers. Even though they are just teenagers, their cognitive ability is beyond the grasp of their peers or even adults. Their development in certain areas may exceed that of their peers; this is called asynchrony development. There are many aspects of asynchrony 
development that distinguish the characteristics of high-ability students. Among these are psychosocial, creative, kinaesthetic, communicative capacity, self-identity, and spirituality. Students who are going through asynchronous development experience uneven development within various domains. One may be very advanced within the cognitive domain but may not be equally developed in the emotional domain of development. Thus, this type of students are capable of comprehending abstract concepts but may not have developed the necessary emotional, holistic skills entailed in coping with these cerebral demands.

The United Kingdom's National Curriculum (2004) stated that students who have deep interest in faith and beliefs will show high levels of insight into the obvious and ordinary. Apart from that, they are able to comprehend and infer meaning from symbols, texts, metaphors and practices. These students also are sensitive to the numinous and are aware of how it can be explored and expressed. Furthermore, they are able to transfer ideas and concepts from one unit of work to another. Finally, they are capable of two further and more generic factors, namely having highly developed skills of comprehension, analysis and research, and secondly, having the ability to think quickly and deeply about a given topic. These students are defined as "those who can easily, quickly and at an expert level, apply specific skills and processes of religious education, and who demonstrate high levels of understanding, insight, maturity and achievement".

\section{High Intensity}

High-ability students display distinctive behaviours indicating the intensity in their thoughts, emotion and interest. They display unique observable behavioural characteristics (Rosadah, Zalizan \&, Noriah, 2004). These behaviours reflect personal values of the students in developing their understanding on how life should be lived. Some individuals showed evidence of heightened spiritual attributes: profound sensitivity and compassion, depth of empathy, integrity, honesty, intuitive inner guidance, living in accordance with equality and justice, and an ability to move beyond everyday reality into oneness with God, nature and the universe (Gatto-Walden, 2009). Theory of potential development by Dabrowski, who was a psychologist, addresses the core of personal characteristics that resonate with behaviour of many gifted children. Dabrowski believed that it was the nature of these students to uphold the principles they believe in, and to attempt to be individuals who are true to themselves (Daniels \& Piechowski, 2009). In searching for the inner self, intensive questioning could lead them further to more questions rather than answers. The questions frequently asked include "Who am I?" and "Who am I to become?". Being teenagers, these students were also going through a difficult phase of their lives. They need support and guidance in understanding the intensity they experience, especially in spirituality. Dealing with these intense urges to understand the concept of faith and belief could affect their wellbeing in the future. High ability students also face risks in their development (Rosadah \& ALliza, 2010). Piechowski (1999) explained that the difference in intensity is an expanded field of subjective experiences. These experiences could increase the spiritual yearnings in order to fulfil the need of understanding the purpose of existence in this world that is bound by morality and wholesome values of one's belief. 


\section{Religious Education}

Religious education in Malaysia is taught as one of the subjects in the national curriculum. It is a subject that has a responsibility to instil religious values in the students' spiritual development. This subject is taught in school from as early as Year One (seven years old) to Form Five (17 years old). One of the outcome of religious education is shaping the students' attitudes in their daily lives (Tamuri, Othman, Dakir, Ismail, Stapa, 2013). At the end of each school year, students are tested on their knowledge of what they have learned. According to Withall (2006), religious education has the capacity to open new realms of thought and experiences for students in the classroom. However, teaching a mixed ability class, by treating the students as one homogenous group does not cater to the unique needs of certain students in the class. Those with high ability needs would find the lessons inadequate to satisfy their yearning for knowledge of spirituality. Therefore, religious education which is taught as a subject, has failed to engage the diverse needs of students in the classroom. For students who have deeper interest in spirituality, they would go further by asking questions on matters that intrigue or challenge their inquisitive minds. They need more than just knowing about religious facts and values. There is a need for them to be have a congruent understanding so as to deeply appreciate and honour the concept of spirituality pertaining to the teaching of belief and faith.

\section{Philosophical Thinking}

Philosophical thinking is an impetus to pursue wisdom. It engages in provocative thoughts about the reality and significance of all existence. Intellectually, high- ability students are capable of, and enjoy exercising their minds in philosophical thoughts. This sometimes brings the mind to extend beyond the mundane world which we live in, to a transcendental world of another dimension. Realizing one's existence in this universe leads one's thought to question and ponder the very reasons behind all of creations. Philosophical thinking is a common characteristic in students who are talented in writing (Piirto, 1992). According to Erickson's Psychosocial Theory, teenagers have an urge to search for personal identities that could lead to formation of their own philosophy of life by actualizing their core belief and faith.

$\mathrm{n}$ yearning for spirituality in life, these young minds need guidance in making the right choices as it could influence the values that they uphold in the future. This could be carried out in religious education classes, especially in the case of teenage students. The teachers responsible need to possess necessary facilitating skills to conduct meaningful discussions. Traits such as tactfulness, honesty, and sincerity are necessary in handling delicate philosophical issues, especially when dealing with teenagers. Thus teachers need to understand and appreciate these students' unique learning needs. It is important to know how these students think and appraise matters and issues pertaining to the meaning of life and existence.

\section{Affective Learning}

Teaching religious education is not merely focusing on the cognitive aspects of learning; it has to be deeply rooted to its affective domain. Affective domains of teaching and learning necessitates 
teachers or instructors to internalize appropriate attitudes in line with the understanding of the lessons learned. Religious education is intended to mould students into acquiring appropriate attitudes and values. Young adolescents at this stage of life are going through a difficult time of seeking identity and sense of belonging according to Erickson's psychosocial theory. The development of their social and emotional aspects during this phase is critical in giving them a balanced emotional state in regards to belief of the faith concerned. Stricker (2009) claimed that affective learning involves the melding of thinking and feeling in how people learn. Phelan (2018) mentioned that high-ability learners tend to have unique learning needs. Thus, it is important that the social learning environment is taken into consideration in the process of gaining knowledge on spirituality. A deeper awareness and understanding of this affective learning is crucial, as it will help educators in choosing the suitable approach in teaching. Guiding and teaching mental dispositions in how a person views, engages, and values learning can result in better understanding and use of knowledge and skills. Learning outcomes are focused on enculturation of norms, values, skilful practices, and dispositions for lifelong learning.

Being gifted, these students are drawn to challenge their minds to understand issues and values of what is going on around them. As their curiosity is triggered in their minds, a vast array of questions needs to be answered succinctly. According to Sisk (2008), gifted youth have spiritual yearning that needs to be addressed properly so as to build the personality of the individuals. The intensity of these youths in searching for answers to global issues can lead to misunderstanding and confusion, which then may lead them to question and doubt their faith and beliefs. Thus, religious education needs to nurture gifted students' characters, in helping them to develop constructive values.

\section{Methodology}

This research focused on assessing gifted students' thinking and learning in order to reflect their philosophy and religious inclination. In assessing the intensity of the characteristics of high-ability students in spirituality, eight items from Piechowsk's Questionnaire on Dabrowski's overexcitability concept of heightened intensity were chosen. The items were used to identify the intensity of the students on characteristics that are closely related in spiritual development. These items were divided into philosophical thinking and affective learning, which are related to the development of spiritual yearning. Each item in the survey used 5-Likert scale ( $1=$ Not at all like me, to 5 = Very much like me).

The sample of this research was a group of participants in a school holiday camp for high- ability students. There were 310 15-year-old students selected for this study. The students, who came from various different schools, were selected by the organizer of the camp after completing two screening tests. These screening tests were on cognitive abilities of the individual to identify highability students for the program. 
DEVELOPMENT

Vol. 8, No. 4, 2019, E-ISSN: 2226-6348 @ 2019 HRMARS

\section{Findings}

The data was analysed to get the mean score on the level of intensity in the aspects of philosophical thinking, and in the aspects of affective learning. The level of intensity of the sample in both aspects was above three (3), which is considered high for these high-ability students.

\begin{tabular}{|l|l|l|l|l|}
\hline Construct & No. & Statement & $\begin{array}{l}\text { Mean } \\
\text { item }\end{array}$ & $\begin{array}{l}\text { Mean } \\
\text { construct }\end{array}$ \\
\hline \multirow{2}{*}{$\begin{array}{l}\text { Philosophical } \\
\text { thinking }\end{array}$} & 1 & I am an independent thinker, & 3.45 & 3.86 \\
\cline { 2 - 4 } & 2 & $\begin{array}{l}\text { I question everything - how things work, what } \\
\text { things mean, why things are the way they are, }\end{array}$ & 3.67 & \\
\cline { 2 - 4 } & 3 & I am moved by beauty in nature, & 4.44 & \\
\cline { 2 - 4 } $\begin{array}{l}\text { Affective } \\
\text { learning }\end{array}$ & 4 & Theories gets my mind going, & 3.90 & \multirow{2}{*}{3.62} \\
\cline { 2 - 4 } & 6 & $\begin{array}{l}\text { I can form new concepts by putting together a a } \\
\text { number of different things, }\end{array}$ & 3.60 & \\
\cline { 2 - 4 } & 7 & I can take everything to heart, & 3.87 & \\
\cline { 2 - 4 } & 8 & I like to dig beneath the surface of issues, & 3.35 & \\
\hline
\end{tabular}

\section{Discussion}

From the findings, it is shown that the participants' level of intensity is distinctively high in both philosophy thinking and affective learning. This intensity combined with their interest in searching for the meaning of life, could lead them to explore the spiritual aspect of life. This showed that high-ability students who have high intensity in these behaviours would be able to discuss and synthesise the concept of spirituality at higher levels than that of their their peers. Combined with their high sensitivity in learning regarding wellbeing in life, this then would spur them to be aware of the need for self-development and betterment of one's self. As affective learning is a way to understand the interpretation of belief, students with high curiosity need guidance to comprehend the richness and depth of faith and beliefs.

Religious education needs an appropriate pedagogy to allow the mind of these inquisitive students to be challenged intellectually in order to fulfil their yearning for wellbeing in life. Teaching and learning process in the classroom should be able to nurture these students' mind to explore existential questions, to evaluate their own and others' responses, and subsequently reassess their own understanding of the matter. It is no longer sufficient to provide these students with knowledge without extensive explanation and discussion of what is being taught (Withall 2006).

In philosophy thinking aspect, the mean of 3.86 showed that these students have provocative thoughts about reality and the significance of all existence. Being moved by beauty in nature has the highest mean (4.4), which showed that the students innately feel the greatness of the creator. They comprehend and appreciate what life is offering them in order to find fulfilment and the wellbeing in living. Tapping this emotion in religious education could be an eye-opener for students regarding the purpose of living in this world that is in accordance with the teaching of 
one's belief. If their minds are constantly thinking about theories independently and only in a cerebral manner, this could push them into greater confusion if they are not guided carefully. These students also highlighted the need to be given the opportunity to think and explore their curious minds. They question everything, seeking to find how things work, what things mean and why things are the way they are. They crave to challenge their own thoughts, trying to find answers to issues and ironies happening around them that are related to values and beliefs.

Being affective learners, the students delve into melding the thinking process and feelings, in attempts to understand how people around them are learning. The social learning environment played an important role in gaining knowledge on spirituality. The students' tendency to dig beneath the surface of issues related to morality and spirituality surrounding them, calls for religious education teachers to encourage students to readily express themselves and discuss meaningfully certain topics of interests. The students cannot help being curious and striving to get to the bottom of certain perplexing questions, be they of social, mundane or existential nature. White (2010) had observed that high-ability learners tend to be critical in their thinking. Therefore, the teachers should avoid being judgemental of students' suggestions or thoughts, but rather help them to see it from the point of the values that should be incorporated in their spirituality. The students have the capability to observe and analyse everything and eventually form new concepts. This could be an alarming sign because without the guidance of educators in religious education, they could be led away from the pillars of the faith that they are constantly trying to comprehend.

Therefore, to cater for the needs of high-ability students who have deep interest in spirituality, religious teachers need to internalize humanistic character traits and embrace virtues and noble values so as to enhance the delivery of religious education, thus further enhancing the wisdom of teaching positive attitudes and values. Religious education teachers are the role models of good conduct and fine characters or being referred to in Arabic as "muaddib and murobbi" (Jaafar, Raus, Muhamad, Ghazalid, Amat, Hassan, Hashim, Ab. Halim Tamuri, Norshidah Mohamed Salleh \& Mohd Isa Hamzah, 2014). Pine and Boy (1997) asserted that the selfactualized humanistic teacher needs to have these characteristics:

1. thinks well of himself/herself and has a good self-concept

2. honest and genuine, there is no conflict between the real inner person and the roleplaying outer person

3. likes and accept others

4. lives by humanistic values, is honestly concerned with the welfare of fellow humans and the improvement of human society

5. is sensitive and responsive to the needs and feelings of others

6. is open to the view point of others, to new information and experiences, and to his or her own inner feelings

7. exercises control over his or her life and environment

8. initiates needed changes

9. is responsive, vibrant, and spontaneous, and tries to live optimistically, and energetically. (Davis and Rimm, 2004) 


\section{Conclusion}

Being intensely interested in spirituality, high-ability students' minds and interests should be challenged positively and guided to the teaching of core spiritual beliefs. Yearning for further knowledge in faith and belief, should be paralleled by the moral values and virtues being taught in religious classes. Therefore, there is a need for suitable pedagogical approaches to teach religious education to these highly intense students. These approaches should stress practising and embracing the teachings of the essential truths of religious beliefs, which are ultimately for the wellbeing of the students, both in current times as well as in the future.

\section{Acknowledgement}

The study was supported by the grant from the Faculty of Education, Universiti Kebangsaan Malaysia, GG-2019-003.

\section{References}

Tamuri, A. H., Othman, M. Y., Dakir, J., Ismail, A. M., Stapa, Z. (2013). Religious education and ethical attitude of Muslim adolescents in Malaysia. Multicultural Education and Technology Journal, 7(4), 257-274. https://doi.org/10.1108/METJ-03-2013-0008

Daniels, S., \& Piechowski, M. M. (2009). Living with intensity. Great Potential Press : USA

Davis, G. A., \& Rimm, S. B. (2004). Education of the gifted and talented (5th ed.). Boston: Pearson Education.

Dollah, M. U., Zabit, M. N. M., \& Omar, T. Z. Z. (2018). Comparing the Value of Control with Characteristic of Prediction Conveyed in Mathematics Textbooks in Malaysia and Australia. International Journal of Academic Research in Progressive Education and Development, 7(4), 387-396.

Gatto-Walden, P. (2009). Living one's spirit song: Transcendent experiences in counselling gifted adults. In S. Daniels \& M. M. Piechowski (Eds.), Living with intensity: Understanding the sensitivity, excitability, and emotional development of gifted children, adolescents, and adults(pp. 203-223). Scottsdale, AZ: Great Potential Press.

Hosseini, M., Elias, H., Krauss, S. E., \& Aishah, S. (2010). A Review Study on Spiritual Intelligence, Adolescence and Spiritual Intelligence, Factors that may Contribute to Individual Differences in Spiritual Intelligence and the Related Theories. Journal of Social Sciences. 6(3): 429-438.

Jaafar, N., Raus, N. M., Muhamad, N. A. F., Ghazalid, N. M., Amat, R. A. M., Hassan, S. S., Hashim, M., Tamuri, A. H., Salleh, N. M., Hamzah, M. I. (2014). Quran Education for Special Children: Teacher as Murabbi. Psychology. 2014. DOI:10.4236/ce.2014.57053

Onyali, C. I., Okerekeoti, C. U. (2018). Board Heterogenity and Corporate Performance of Firms in Nigeria, International Journal of Academic Research in Accounting, Finance and Management Sciences 8 (3): 103- 117.

Palmer, P. (1999). Evoking the spirit in public education. Educational Leadership, 56(4), 7-11.

Phelan, D. A. (2018). Social and Emotional Learning Needs of Gifted Students. Ed.D Dissertation. Walden University. USA. Walden Dissertations and Doctoral Studies 
Phenwan, T., Peerawong, T., Tulathamkij, K. (2019). The Meaning of Spirituality and Spiritual Well-Being among Thai Breast Cancer Patients: A Qualitative Study. Indian Journal of Palliative Care. 2019 Jan-Mar; 25(1): 119-123. doi: 10.4103/IJPC.IJPC_101_18

Piechowski, M. M. (1999). Overexcitabilities. In M. Runco \& S. Pritzker (Eds) Encyclopadea of creativity (vol 2 pp 325-334) New York: Academic Press.

Piirto, J. (1992). Understanding those who create. Tempe, AZ: Gifted Psychology Press.

Pine, G. J., \& Boy, A. V. (1997). Learner Centered Teaching: A Humanistic View in Davis, G. A., \& Rimm, S. B. (2004). Education of the gifted and talented (5th ed.). Boston: Pearson Education.

Majid, R. A., Jelas, Z. M., \& Ishak, N. M. (2004). Behavioral Characteristics Prototypes of Academically Talented Students: Implications on Educational Interventions, Paper presented at Gifted Education Conference, NIE, Nanyang Technology University, Singapore.

Majid, R. A., Alias, A. (2010). Consequences of Risk Factors in the Development of Gifted Children. Procedia Social and Behavioral Sciences 7(C) (2010) 63-69.

Sisk, D. (2008). Engaging to Spiritual Intelligence of Gifted Students to Build Global Awareness in the Classroom. Roeper Review 30: 24-30.

Stricker, A. G. (2009). Why Affective Learning in a Situated Place Matters for the Millennial Generation. http://www.au.af.mil/au/a46i/documents/Why-Affective-Learning-in-aSituated-Place.pdf

The National Curriculum United Kingdom's website (2004). (www.nc.uk.net/gt/re/index.htm).

White, D. A. (2010). Thinking (With Help from Aristotle) About Critical Thinking. Gifted Child Today. Summer 2010. 33(3): 14-19.

Whittall, A. (2006). Using the Interpretive approach for teaching RE to gifted and talented pupils at Key Stage 3. http://www.farmington.ac

Zalizan, M. J., Ali, M. M. (2014). Inclusive education in Malaysia: Policy and practice. International Journal of Inclusive Education, 18(10), 991-1003.

https://doi.org/10.1080/13603116.2012.693398 